
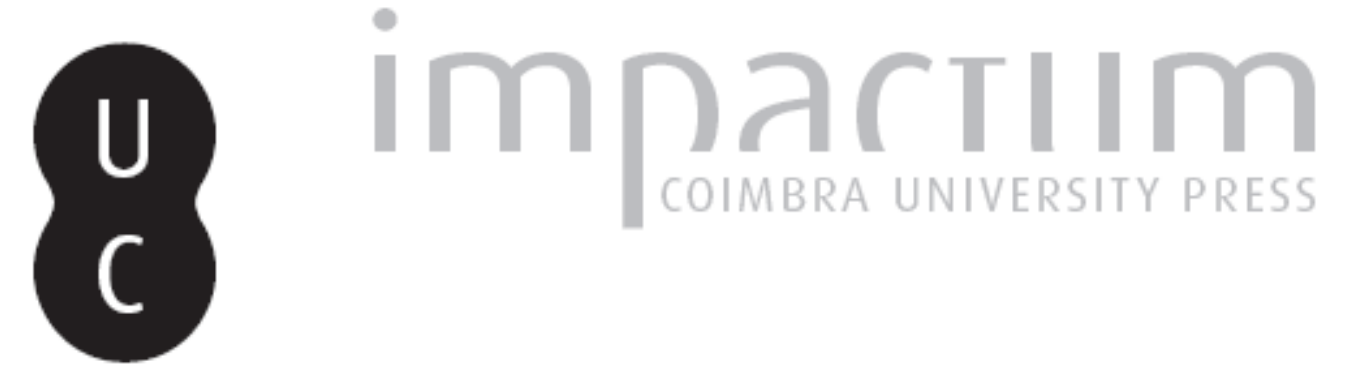

\title{
An electronic edition of eighteenth-century drama: the materiality of editing in performance
}

\author{
Autor(es): $\quad$ Pinto, Isabel
}

Publicado por: Centro de Literatura Portuguesa; Imprensa da Universidade de Coimbra

URL

persistente:

URI:http://hdl.handle.net/10316.2/39103

DOI:

DOI:http://dx.doi.org/10.14195/2182-8830_4-2_9

Accessed : $\quad$ 26-Apr-2023 14:10:58

A navegação consulta e descarregamento dos títulos inseridos nas Bibliotecas Digitais UC Digitalis, UC Pombalina e UC Impactum, pressupõem a aceitação plena e sem reservas dos Termos e Condições de Uso destas Bibliotecas Digitais, disponíveis em https://digitalis.uc.pt/pt-pt/termos.

Conforme exposto nos referidos Termos e Condições de Uso, o descarregamento de títulos de acesso restrito requer uma licença válida de autorização devendo o utilizador aceder ao(s) documento(s) a partir de um endereço de IP da instituição detentora da supramencionada licença.

Ao utilizador é apenas permitido o descarregamento para uso pessoal, pelo que o emprego do(s) título(s) descarregado(s) para outro fim, designadamente comercial, carece de autorização do respetivo autor ou editor da obra.

Na medida em que todas as obras da UC Digitalis se encontram protegidas pelo Código do Direito de Autor e Direitos Conexos e demais legislação aplicável, toda a cópia, parcial ou total, deste documento, nos casos em que é legalmente admitida, deverá conter ou fazer-se acompanhar por este aviso.

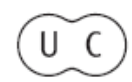



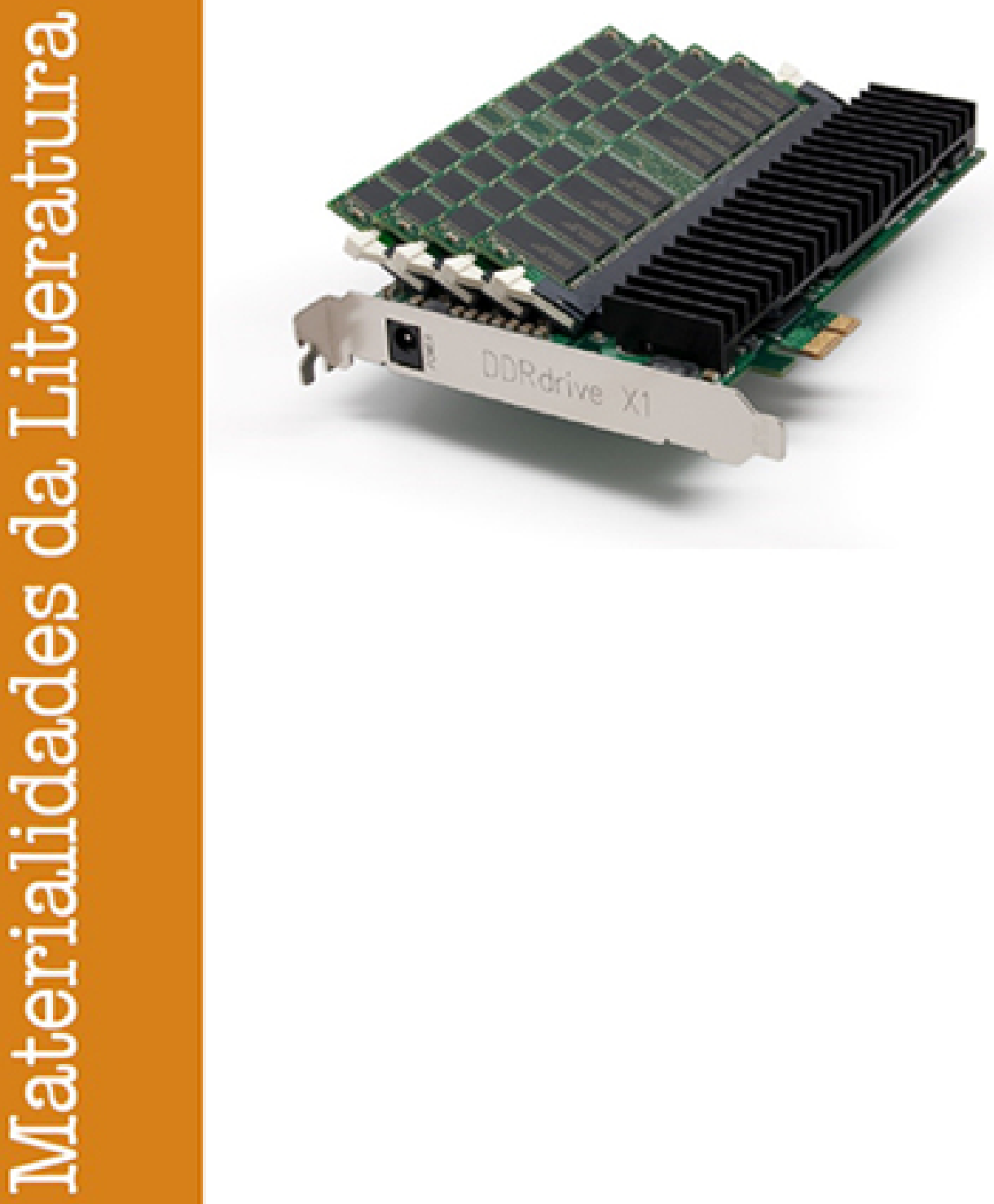

Vol. 4.2 (2016) ISSN 2182-8830

'Estudos Literários Digitais 2'

Manuel Portela e António Rito Silva (orgs.) 


\title{
An Electronic Edition of Eighteenth-Century Drama: The Materiality of Editing in Performance ISABEL PINTO \\ CIDEHUS | Évora University \\ FCT Post-Doctoral Research Fellow
}

\begin{abstract}
In the domain of electronic edition, drama's specificity has been considered in terms of metadata improvements and possibilities. At the same time, an increasing closeness between art history research and performance art has demonstrated its methodological value to assess the complex nature of the archive. My post-doctoral research follows the lead and goes as far as proposing that performance art can be an adequate methodology when preparing the electronic edition of eighteenth-century drama. Furthermore, "performing the archive" can help to fill the gap between the eventful nature of drama manuscripts and the audience of today, suggesting new ways of approaching the specific materiality of the plays. Keywords: electronic edition; eighteenth-century drama; manuscripts; archive; performance art.
\end{abstract}

Resumo

No âmbito da edição electrónica, a especificidade do género dramático já mereceu atenção, mormente no que diz respeito a usos optimizados de metadata. Paralelamente, uma crescente proximidade entre investigação histórica e performance art constitui uma mais-valia para redimensionarmos o conceito de arquivo na actualidade. Assim, a minha investigação de pós-doutoramento baseia-se nos pressupostos enunciados para defender que a performance art é uma metodologia válida e adequada no curso da preparação de uma edição digital de teatro do século XVIII. Consequentemente, "performing the archive" viabiliza uma relação entre a natureza performativa de manuscritos de teatro e o público de hoje, corroborando, desta forma, novas abordagens à materialidade das peças. Palavras-chave: edição electrónica; teatro do século XVIII; manuscritos; arquivo; performance art.

$\mathbf{T}$

his article addresses a project of electronic edition of eighteenthcentury drama manuscripts, introducing performance art as an active methodology (Clarke, 2013). This was meant to isolate the specific features of eighteenth-century drama manuscripts, in order to assess their improved electronic edition. So, to fully grasp the distinctive features of these historical testimonies, I used performance art as a mediation process, and was directly involved in different performance initiatives.

Through performance I was able to restitute the "take place" (Kobialka, 2002) i.e. the eventful nature contained in the manuscripts, instead of search- 
ing for metadata innovations, or an ideal critical apparatus. It was drama as a particular type of live event and accomplishment, silenced amidst the archive, that most interested me. The eventful quality of the manuscripts was then put to proof through different contexts and practices of performance that even tested the materiality of editing itself, attached from its beginning to the multilayered materiality of the source text. The resulting digital edition reflects the "remains" of taking drama manuscripts into performance practice, allowing for a new format of reading material, which privileges the relationship between screen display and enactment.

In this context, both live performance and video-performance relate to the challenge of bringing to life a particular textual witness from the archive. In this way, they not only become a metaphor for the performative intervention inherent in the editorial act, but they further assert the adequacy of a more literal performative approach to editing, especially in the case of dramatic literature. Thus, pondering the range of implications associated to the concept of "performative materiality" (Drucker, 2013) can illuminate to what extent editorial choices respond to different forms of materiality.

\section{Digital Edition: Concepts in Review}

As I introduce below a new theoretical approach to editing that attends to its multilayered materiality and a new practical approach adopting performance art as a methodology for editing, I shall first overview some fundamental points concerning the theory of digital editing.

The electronic environment of hyperediting overcomes the codex-based limits, according to McGann (1997), as computerization can optimize the logical categories of traditional critical editing that can then acquire new functions. In fact, to function in a "hyper" mode, an editing project must use computerization in such a way as to get over the analytic limits of hardcopy text. He further recognizes the relevance of hyperediting projects, since hypermedia editions offer the possibility of incorporating audio and/or visual elements that capture the multimedia nature of literary works: "texts are language visible, auditional, and intellectual (gesture and (type)script, voice and instrumentation, syntax and usage)" (33). McGann (1997) also introduces a distinction between archive and edition. Curiously enough, the author explicitly links the term edition to a book format, with its specific categories of production and dissemination, while emphasizing the unlimited expansion potential of both the contents and web of relations of a hypermedia archive.

However, in more recent years the functionality of the book format in digital environments became a subject matter for discussion. Notably, Drucker (2009) calls attention to the fallacious way we have come to analyze and see the book format. She further claims that it is necessary to correctly identify the specific features of a material form to then be able to envision its 
functionality in a new medial format. In her view, until now the focus has been on the reproduction of the graphic and physical features of the book through digital media, whilst the expansion of the functionalities of the book would have been a better option.

The expansion of tools and means for dealing with texts that the digital represents is also a major concern in Deegan and Sutherland (2009). They go as far as to consider that digital tools imply a revision of the concept of text itself and its defining features. Building on the topic, Dahlström (2009) argues against idealistic notions of documents, texts and editions, as he claims that the nature of editions is rhetorical, social and one that entails complex translation rather than simple transmission.

In the domain of electronic editing, a range of possibilities arise, going from the hypermedia multilayered archive, involving multiple research partnerships, to individual manuscript editions. Focusing on scholarly editions, Vanhoutte (2009) notes how their audience is both small and specialized. Hence, in his view, this current practice of editing, with its rather dense critical apparatus, causes the dismissal of the scholarly edition as a cultural product. Vanhoutte's main argument is that the qualifying characteristic of an edition lies in the status of its text, not in its function, form of appearance, or even method. The electronic edition is thus seen as the optimized medium for the promotion of the scholarly reading edition, fitting in as a compromise between the scholarly requirements and the cultural demands of the present. Nevertheless, and despite well-intentioned attempts to customize the scholarly edition, McGann (1997) points out that

But for the scientist and scholar, the media of expression are primarily conceptual utilities, means rather than ends. Scholars often seek to evade or supercede an expressive form to the extent that it hinders the conceptual goal (whether it be theoretical or practical) (20)

This brief theoretical overview shows that despite the many possibilities prompted by the digital an equal number of challenges still lie ahead, particularly in what concerns the craft of editing. Whether it be the clever appropriation of the book format, the revision of the status of the text, the shift in editing models or the more general consideration of the "expressive form", editing in a digital environment is surrounded by as many questions as decisions regarding the optimization of tools toward an improved user experience.

\subsection{Editing Drama and Performance Digitally: Approaches and Methods}

This section reviews three scholarly projects that deal specifically with the digital edition of drama and performance. Taking them to be representative 
of the state of the art in the area, I will briefly cover their main goals, characteristics and intended outcomes.

The general goal of The Cambridge Edition of the Works of Ben Jonson is to reedit the Jonson canon for academic use through updated historical, literary and textual approaches and to present the outcomes of this initiative in a comprehensive and well organized structure that relies on all modes of textual reproduction.

Unlike other digital archives that remain peculiarly static and rigid, providing for the possibility of addition but not reorganization of material, the CEWBJ seeks to explore electronic textuality by embracing emerging technologies to lend editorial power to the users that will be encouraged not so much to find as to make order. Therefore, concurrent with the shift in editorial design from hierarchical to "rhyzomatic", "a term that comes from the tangled root structure beneath a field of grass, a non-hierarchical mass of ever-growing links between and among tufts" (Gants, 2006: 124), a series of intensive research and development initiatives achieve increasing robust delivery modes of this resource, highlighting both Jonson's processes of composition and the editorial choices which ground the modernized edition of his texts.

The Project Shakespeare His Contemporaries comprises a vast corpus of plays, printed before 1660, made available online to function as metadata, considering that "a quite explicit and rigid system of metadata is part of the genre itself' (Mueller, 2014). Plays are divided into speeches, scenes, and acts and they are constituted by stage directions and speaker labels. Since its metadata is so explicit and consistent across many texts, drama is a genre particularly suitable for digital mapping, displaying quite precise guidelines about how to transform the texts into a "machine-actionable corpus". Thus, this project aims to deal with the specificity of drama in terms of digital mapping and metadata.

In the context of the project PO.EX: A Digital Archive of Portuguese Experimental Literature, Portela (2014) calls attention to the diverse media of Portuguese experimental literature, comprising "visual poetry, sound poetry, videopoetry, performance poetry, computer poetry, and several other forms of experimental writing". In assessing the different types of materiality that ought to have a digital representation within the project, Portela distinguishes a performative one referring to live events. In order to find the most adequate digital representation for performative materiality, original documents, such as recordings, audio, video, film and photography, were selected. However, the means to assess the live events that entail the performative dimension of the PO.EX project was not performance itself but video and audio recordings instead.

Differently, I contend that performance can be a legitimate methodology toward an editorial decision on the right digital representation. I am then suggesting that when it comes to drama and performance, it would be effec- 
tive, at least at times, to replace the rationale of patterns, analogies and metadata by the "take place" theorized by Kobialka (2002). Additionally, drama projects, as argued, seem particularly fitted for metadata, mainly due to the texts' standardized structure, which sustain inferences that can help to organize the drama production of a historical period. From this starting point, I consider a first level of performance that consists of a performative demonstration of the interplay between different materialities within the act of editing, and their influence upon its development. In the next section, I fully embrace the "expressive form" (McGann, 1997: 20), since through an engagement with the materiality of editing it becomes evident how counterproductive is its dismissal.

\section{On the Materiality of Editing}

My intention now is to illustrate the influence of different layers of materiality in the process and outcome of editing. Even more strikingly, I contend that coupling editing with materiality implies a peculiar approach to dramatic literature, one which expands on the inherent performance of the editor's hand.

Within the material nature of the act of editing, some important points have been made regarding either the editor's profile and craft (Gross, 1993; Gordon, 2015) or the implications of digital materiality (Manoff, 2006; Kirschenbaum, 2008; Drucker, 2013). In relation to the editor's craft, Gordon (2015) deals with the specific implications of the author's death, or, in other words, how editors reconcile the death of their main subjects with the textual interventions required by editing. As a challenge, this circumstance offers a number of possibilities in terms of pondering the editor's narrative options. It is then acknowledged that the "editor's narrative is more akin to the biographer's than to the storyteller's". This assumption often takes up the practice of chronological editing of texts, documents and papers, aiming to present the author's work over time in a comprehensive manner. Rather overtly, most editors refuse to be the narrators of their own editions, engaging in a fruitful collaboration with the principal subject of their work instead. Nevertheless, it is also recognized that the "editor's hand and voice is all over the editions, working in collaboration with the subject, whether overtly or not". Taking all this in account, we can infer that the editor's craft mediates between the author's work and the world, considering its power to decide upon the narrative that roots that same work.

Kirschenbaum (2008) conceptualizes the meaning of materiality in a digital environment. For that, he makes use of the notions "forensic materiality" and "formal materiality". The first is akin to the flux of changes that affects matter, opening it up for individualization: "forensic materiality rests upon the principle of individualization (basic to modern forensic science and crim- 
inalistics), the idea that no two things in the physical world are ever exactly alike" (10). On the other hand, formal materiality is based on symbols that allow for the illusion of constant patterned behavior: "Formal materiality thus follows as the name I give to the imposition of multiple relational computational states on a data set or digital object" (12). These two categories articulate two complementary dimensions of digital materiality.

By pursuing an interdisciplinary survey that calls into play a range of fields, from cultural studies to cognitive science, Drucker (2013) reframes digital materiality within the notion of "performative materiality," as a way to draw emphasis on the operative dimension of the artifact: "Performative materiality suggests that what something is has to be understood in terms of what it does, how it works within machinic, systemic, and cultural domains". With this notion, Drucker offers an analytical framework for interweaving materiality with performance, one whose focus shifts from entities to events and from closed and stable notions to a contingent operating materiality. This new approach can be used to rethink the design of digital humanities projects, starting with a model of interface that reshapes its use and further appeals to argumentation and intellectual engagement. Anchored on critical theory's traditions, from structuralism to ecocriticism, the user interface should enable and facilitate a set of interpretative events.

However, it is also necessary to pin down the materialities editors have to handle whilst dealing with their working material. As a contribution to that, in what follows I address how different materialities successively influenced my course of action as editor. In doing this, my major concern lies within the materiality of editing, envisioned at the intersection of the editor's craft and the materiality of the text. Accordingly, I shall report to my own experience of editing eighteenth-century manuscript dramas, as the manuscripts' material conditions, poised between their eighteenth-century production and twenty-first century consumption, will function as an inscriptional base from which the eventive nature of the editor's craft emerges, in other words "materiality provokes the performance" (Drucker, 2013). The materiality of editing is based on the interaction with the materiality of the primary source and expands itself through its subsequent transformation and adaptation.

\section{Uncovering Material Layers in Eighteenth-Century Manuscript Drama}

Drawing on the theoretical considerations aforementioned, we get the idea that editing builds on both the forensic materiality and the formal materiality within the principal subject's work. Regarding the drama manuscripts with which I am most concerned here, forensic materiality attaches an unique arrangement of paper and ink to a particular title, based on a combination of a certain type of paper, its foliation and a certain distribution of ink over it; in 
respect to formal materiality, the fixed structure of drama, divided into speeches and stage directions, determines its interpretation. In particular, the forensic level of inscription enables the textual investment framing the manuscript as cultural object. These two dimensions configure, firstly, the editing experience and, secondly, the edition's reception. In particular, the way the editor's hand and voice move along these weaving materialities has a direct impact on the range of interpretative processes they are to enable. In other words, the editor's course of action has direct implications on the performative materiality of the edition whether in a digital environment or not. As a consequence, it becomes evident that the editor's craft is deeply embedded in different content-driven notions, such as performative materiality, and interacts with the types of materiality embodied in cultural artifacts, like forensic and formal materialities.

My awareness of the materiality of the process of editing was enhanced by my encounter with the digitized manuscript. In fact, the theatre collection of António José de Oliveira (1780-1797), containing more than two hundred manuscripts, is available online at the National Digital Library. ${ }^{1}$ Because we are dealing with manuscripts, the scribe's technical expertise imposes on us, through a particular spacing of the copy on the page, the type of ink used, the distribution of catchwords, the use of punctuation marks, etc. According to Kirschenbaum's typology, the "forensic materiality" of the manuscript is rather evident based on the acknowledgment of paper and ink specificities, as aforementioned. Furthermore, in the case of manuscript drama, we still have to consider the formal materiality attached to the division into acts and scenes, indication of characters, integration of the stage directions and introduction of arias and other songs in the text. In short, the materiality of the manuscript rests to a large extent on the interplay between the physical properties of the inscriptions and the layout conventions which give them specific functions. The scribe's expertise is responsible for introducing a major difference between editing a manuscript or a print material. Of course, when dealing with print material the materiality of the type of printing chosen is also called forth, but still print offers a range of options that more easily fall under more straight and recognizable patterns than manuscript sources.

Manuscript culture is under the influence of the individuality of the scribe. This is one additional feature to take in consideration when editing a manuscript. There is no such degree of individuality to consider when editing a printed source. The typographical layout suits a range of different texts and literary genres, with mainly increasing readership in mind. In contrast, manuscripts befitted more peculiar functions and usage, as they were ordered by individuals with their own goals and aims. The scribe revealed its expertise in fulfilling the specifications of a particular order. These two spheres of activity mutually influenced one another, with the scribe using as layout strategies

${ }^{1}$ http: $/ /$ www.bnportugal.pt $/$ index.php?option $=$ com_content\&view $=$ article\&id $=956$ 
some typographical conventions, like the clear division in acts and scenes through the use of capital letters and bold, and the printers also turning to manuscript resources to enhance their books and pamphlets with, for instance, an asterisk signaling the stage directions. So, in both layouts, the division in acts and scenes is granted, and the distinction between speeches and stage directions is equally preserved. However, the tendency is for the printed material to address the latter aspect in more assertive terms, since, contrarily to what happens in manuscripts, it most commonly displays the stage directions separately from the main text in footnotes.

From the materiality of the manuscript, I had to grasp the genre and linguistic materiality of each play: if the play was in prose or in verse, or a mixture of both; if the characters were consistently named or not; the expressive use of graphic signs like parentheses and of punctuation marks like ellipsis; the indication of asides, etc. In other words, although I was editing manuscript drama, each play corresponded to a different manuscript, bringing forth a unique combination in terms of layout. Whenever dealing with the materiality of dramatic literature, it is wise to further test the adequacy of transcription criteria. In fact, transcription criteria can be seen as a direct response to both the forensic and the formal materiality of a particular text.

In this phase, the editor is already handling the materiality of the edition too, seeking to fully envision a particular cultural artifact i.e. a certain type of edition. Page by page, the editor transcribes the text, without failing to acknowledge the material layers involved in accessing dramatic literature, the repertoire and the stage. In order to succeed, the editor must place himself/herself somewhere in between the time of the production of the manuscript and the time of the text, and his/her own time, when the edition is just trying to find its way out. Although, the editor cannot go back into, for instance, the eighteenth century, it is for him/her likewise impossible to ignore the context and the circumstances surrounding the production of a certain manuscript drama; it is the edition not the text that belongs to the present moment. Additionally, the fact that dramatic literature shapes its characters through their speeches brings about a specific textual feature. This phenomenon is put to proof, when, for instance, the editor is confronted with a scribe's error in the attribution of a speech. As editor, it becomes relatively easy to spot that a particular character could never have produced such a speech. Since characters are compelled to find their way amongst an arena of argumentation, as editor one must know each character's stance.

Once the edition is finished, as a FINAL file.doc in the editor's computer, another phase might come along and the process might be extended: the materiality of the edition, namely its graphical layout, can befit the materiality of the book. For that, a number of adaptations and adjustments are needed. First of all, a number of requirements are set depending on the kind of series the edition is going to integrate. From the number of pages to font families, 
the materiality of the book as a cultural and commercial product dictates its own identity and reproducibility.

On 16 April 2015, I promoted a session to present my book edition of The New and True Story about the Queen of Volsco's Triumph (1783/ 2015) and, at the same time, to discuss the topic of what I called the materiality of editing. My leading intention was to describe and explain the craft of editing to a non-specialized audience. I wanted non-specialists to be able to understand what editing means and the kind of gestures it comprises. In order to accomplish that, I staged the concept of "performative materiality", as I used specific materials, namely a ladder, a velvet dress, a reproduction of the front page of the primary source, pages of the draft of my edition and the final published book to unfold the process of editing, with its specific phases and outcomes. Each material / materiality played a specific role in the performance (Figure 1).

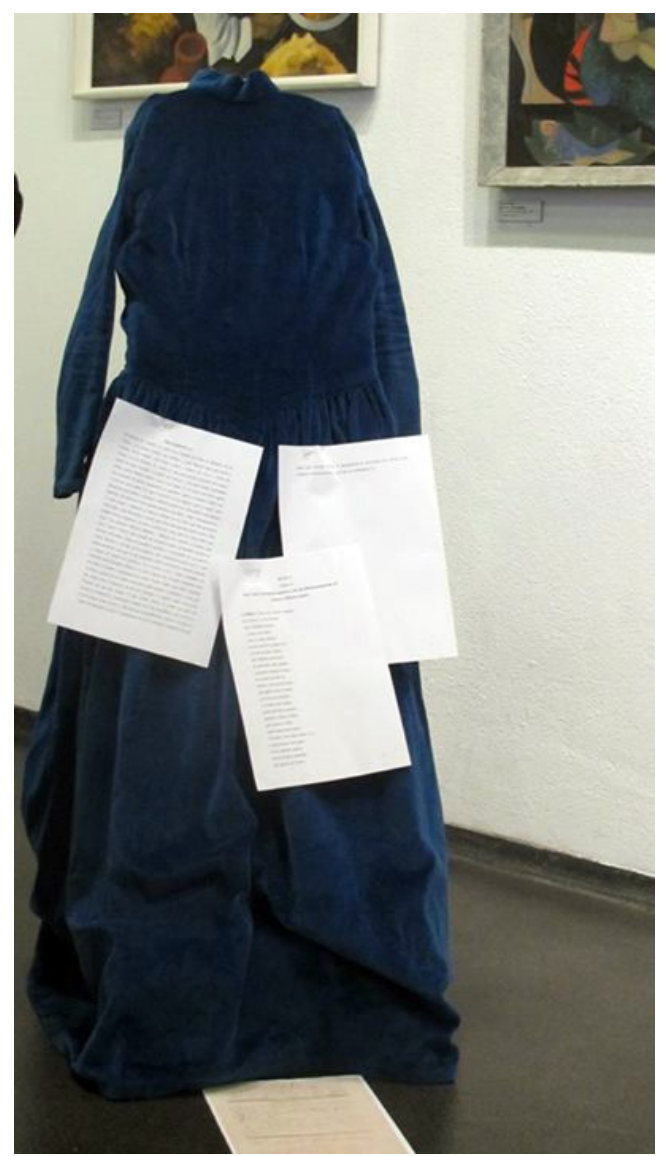

Figure 1. The New and True Story about the Queen of Volsco's Triumph: Assessing the Materiality of Editing. Casa da Achada, Lisbon, April 16, 2015. Photo: Freya Group. 
The ladder was the first element to be called for, signaling to what extent editing was a means of producing a cultural construct. Then, the dress was used to mark the disposition and will of the editor to embrace a different historical period and, consequently, a different understanding of the world. The manuscript, placed at the bottom of the dress, pointed out to the critical moment of the editor's confrontation with the materiality of the source prompting the edition, insofar as a first level of the edition's materiality is embedded in the manuscript itself.

After that, several pages of edited try-outs covered the skirt of the dress, as a way to attest the consistency of the materiality of the edition. The confrontation between the editor and the manuscript led to a new layer of materiality that not so much reproduced the manuscript integrity but rather transformed it. During this phase, the editor embraced both the scribe's apparatus and the alterity enabled by the correspondence between characters and speeches, assessing and refining criteria and methods for transcribing. Overall, it can be understood as an experimental phase that hopes to end with a coherent reading and a staging proposal as outcomes. In the present case, the final version of the edition i.e. that hopefully coherent reading and acting proposal gave rise to a book, but only after a series of required adjustments between different materialities, that of manuscripts in general, of each play in particular and of the draft versions of the edition itself. In my presentation, the book was topped at the end, placed as the head of the editing persona, making reference both to another layer of materiality, ensuing from the book format, and to a society that still relies on the book as major cultural product (Figure 2).

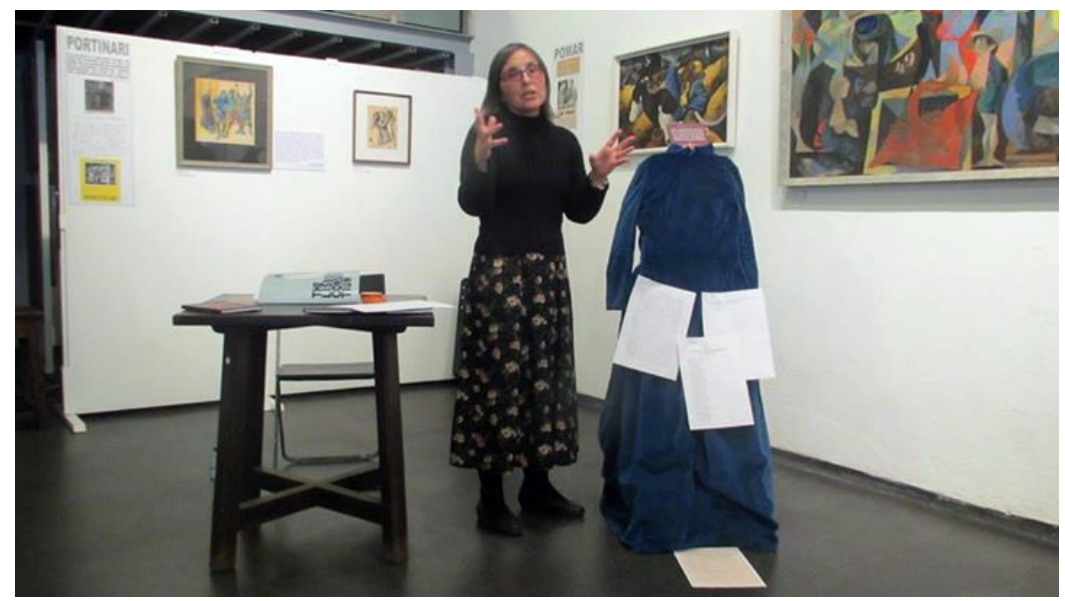

Figure 2. The New and True Story about the Queen of Volsco's Triumph: Assessing the Materiality of Editing. Casa da Achada, Lisbon, April 16, 2015. Photo: Freya Group.

In summary, the materiality of the editor's hand and voice implies that there is no such thing as a straightforward textual version. Through the lenses 
of materiality, referring both to physical and formal characteristics, and the tasks entailed and derived from acknowledging them, manuscripts, drafts and books allow for different reading gestures and interpretative processes. Although interrelated, they all bear an intellectual integrity on their own, as a cultural construct that traces a particular literary and performative practice.

Indeed, the editor's narrative begins with the assessment of the layers of materiality involved in the source text which, in turn, justifies itself by drawing the necessary emphasis on the interplay between the act of editing and the cultural as well as the material circumstances that circumscribe it.

\section{Editing Eighteenth-Century Drama Manuscripts Digitally}

In this section, I address the details of my own project of electronic edition, and I start by presenting the theatre collection from which it unfolds. Then, the description of three performances, two live and one in video, exemplify a new methodological insight into editing. This resulted from an experimental articulation between editing and materiality, as theorized and performed in the previous section.

Thirty four "in oitavo" volumes of plays are kept at the National Library of Portugal (Figure 3). They were copied between 1780 and 1797 by António José de Oliveira, a professional scribe. Each volume contains five or six texts. The majority are in Portuguese (some are bilingual, i.e., also in Italian), and names like Carlo Goldoni, François d'Arnaud, Giovanni Guarini are among the known authors. Each of the manuscript volumes seems arbitrary in its organization, mixing genres (comedy, tragedy, drama, farce, etc.) and dates.
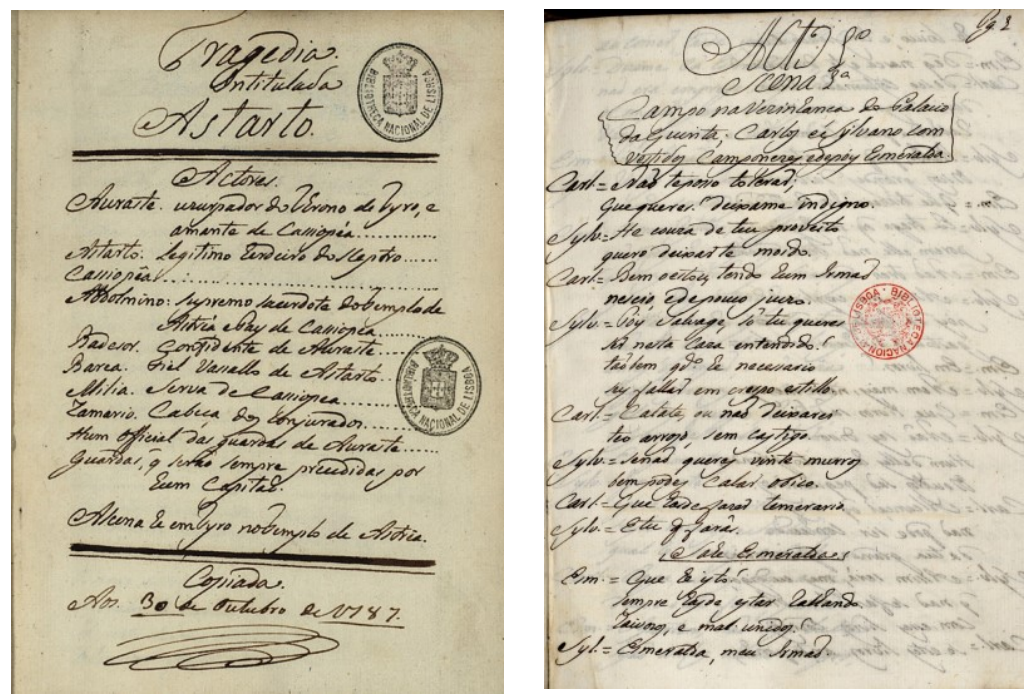

Figure 3. A collection of eighteenth-century manuscript plays kept at the National Library of Portugal. 
The project was launched online on January 2015 at the site of the Research Centre for Communication and Culture, where I have been developing my post-doctoral research on the collection. For now, it is composed of a sample of eight titles from the collection of António José de Oliveira that were never published before. ${ }^{2}$

As this is the first edition of the plays, there was neither a printed version to help me decide what digital format to give the archive nor a past book to direct my mind to a certain mise-en-page. As I understand, these plays are hybrid reading material, a work in progress reading material, in the sense that they refer to a materiality outside the text, i.e. performance, even if indirectly.

The majority of the manuscripts within the collection were produced to be assessed by the censorship court so that a decision concerning the license for performing or printing a certain play could be reached. So, a concept of book or even of e-book was never envisioned, also because I was determined to think the edition's layout outside that frame and the constraints it implies. In other words, I was more interested in looking at the manuscripts as performance testimonies than as written material.

Instead, with this edition project, I wanted to look thoroughly at the specificities that drama manuscripts were to bring along to the process. Their eventful nature (Kobialka, 2002) was the first criteria considered when choosing a methodology. Therefore, this is not mainly a project of edition of eighteenth-century authorized authors or canonical texts, but one that started by recognizing the impact of the dramatic genre throughout history. Accordingly, this project takes dramatic performance into consideration and seeks ways to reflect and encode it for a digital environment, bringing into play the dynamics between the archive and performance art. Overall, it seeks to facilitate the use of the archive as creative stimulus.

The relationship between archive and performance was the focus of the foundational contribution of Schneider (2001). There the ephemeral nature of performance is revised against the permanence of the archive, as Schneider proposes that "performance remains" attest to the impact of performance well beyond its moment of realization as its memory and cultural legacy span different times and spaces, articulating an embodied transmission of cultural knowledge. The same principle applied to my edited plays, in the sense that by performing with and through them I kept a memory of these live events that afterwards was worthy of consideration in the shaping of

2 The titles are: Molière ou Segunda Parte de Tartufo [Molière or The Second Part of Tartuffe] (1782), by Carlo Goldoni; O Homem Vencedor [The Winner] (1782); Ulisses em Lisboa [Ulysses in Lisbon] (1782), by Francisco José Freire; Nova e Verdadeira História do Triunfo da Rainha de Volsco [The New and True Story about the Queen of Volsco's Triumph] (1783), by Jerónima Luísa da Silveira; Não se Vence a Natureza [Nature Cannot be Defeated] (1784); Mafoma ou Fanatismo [Fanaticism or Mahomet The Prophet] (1795), by Voltaire; O V assalo Mais Fiel no Cerco de Guimarães [The Most Loyal Servant in the Siege of Guimarães] (1796); As Constâncias de Belisário na sua Maior Decadência [Bélisaire] (n.d.), by Jean-François Marmontel. 
their digital display. In this sense, using historical manuscripts, easily recognizable as cultural artifacts, to mediate between myself, as an individual, and the audience, or staging scenes from a puppet opera, led to an insight into the primary information to consider when bringing these plays alive through performance.

By taking performance as a methodology for editing, I also intended to contribute to the dynamics between archive and repertoire, as suggested by Taylor (2003). In each performance involving plays from the collection I, the performer, was trying to expand the challenge of editing. The archive is written, institutional and authoritative, whilst the repertoire, understood as embodied memory, participates in the storing and transmission of knowledge through varying types of performance based on non-written codes, such as gestures, movement, dance, spoken word and song. Performance transmits cultural memory and can transform and redefine the archive, inasmuch as the repertoire is part of an active everyday transmission of memory and identity.

So, by performing with and through manuscripts I have come to participate in the ongoing process of embodied transmission and production of knowledge. As a result, the edited plays took part in a repertoire which transmits and reinvents cultural knowledge, memory and identity. These plays were, thus, inscribed into the twentieth-first century embodied practices, in dialogue with other contemporary productions of cultural revision.

The total corpus of my edition project is fifteen texts. ${ }^{3}$ And this can hardly be considered a vast corpus of plays to be treated and dealt with in terms of metadata patterns. Alternatively, I am interested in exploring the relationship between the archive and performance as a tool for improved digital edition. Thus, the "performance remains" of the repertoire will continue to guide the electronic edition of the archive, a collection of eighteenthcentury Portuguese drama manuscripts, insofar as textual traces of performance contained in the manuscripts will be further acknowledged and rethought both through live performance and editing. In this particular case, drama's specificity, as partially accounted for in Mueller (2014), was explored as predisposition to an embodied transmission and production of knowledge i.e. the repertoire, that was then used in the preparation of an electronic reading edition that mostly aimed to prompt a performative engagement with each play, whether through live performance, theatrical production, or public reading.

3 The titles still in preparation are: O Criado Astucioso [The Witty Servant] (1781); Semiramis em Babilónia [Semiramis in Babylon] (1784), by Alexandre António de Lima; Licasto e Mitilene [Licasto and Mitilene] (1786); O Tartufo Lusitano e a Mulher Vingativa ou O Disfarcado Hipócrita [The Lusitan Tartuffe and the Revengeous Woman or The Hypocrite Disguised] (1796); Muito vence amor e engano ou O Ignorante por Sábio Admitido [Love and hoax win a lot or The Ignorant Taken for a Wise Man] (1796); Os Encantos de Medeia, $3^{a}$ parte [The Enchantments of Medea, $3 r d$ part] (n.d.), by António José da Silva; Sem Ingratidão Ingrato [The Ungrateful Without Ungratefulness] (n.d.). 


\subsection{Performing for Editing}

In this section, which signals the transition from the individual research into the public domain of performance, I document three performances, two live and one on video, occurred in very different spaces that, in the whole, aim to disclose the historical link that guides my postdoctoral research to the broader audience. They were a means to culturally reconfigure the manuscripts of my study that thereby became part of the repertoire. In this sense, the promoted performances, besides being a privileged means of disseminating my theatre history project, reconfigured my desk research around eighteenthcentury theatre. Performance enabled both the materiality of the manuscripts and that of drama to expand, thereby calling forth a new interpretative process that, in turn, allowed a fresh understanding of the notions of heritage and legacy. Through this culturally significant reconfiguration, both manuscripts and drama reclaimed an embodied accuracy that pertained to the eventful nature of theatre and performance. The term 'accuracy' retrieves the significance of the textual traces of performance within the manuscripts, in terms of live performance and subsequent editing. In this context, the choices surrounding the textual traces of performance either in live performance or in editing must express accuracy in relation to one another. Overall, the experience of taking the performative materiality of manuscript drama to its limits proved decisive to envision the performative materiality of the edition itself.

\subsubsection{Manuscripts or, the Upheaval of the Body}

On 20 December 2013, I premiered "Manuscript Play" at Boavista Gallery, in Lisbon, with another performer, Eunice da Silva, from Freya group. It was an event organized by Demimonde, a group of performance practitioners from different backgrounds. The setting was rather unpretentious, with only a table, a few chairs and a pillar with hanging manuscripts. Mostly, I wanted the audience to become interested in my research work, and, in particular, I wanted them to be willing to "try out" the manuscripts I have embraced for some years now. I started the performance with a short presentation of myself and my research work, underlying the circumstance that we, I and the audience, shared a social order of production and consumption where my main work was expected to consist in the reading of eighteenth-century drama manuscripts. This was the general background intended to contextualize what followed.

I interacted with the manuscripts through physical actions: I carried them around, laid my upper body on them, sheltered behind them, escaping from exposing too much of myself (Figure 4), and pushed them around... All my movements were driven by and toward them. On the one hand, I 
wanted to experience the collection in a renewed fashion that did not entail reading, analyzing, studying, but rather expressed closeness and a sense of belonging. On the other hand, my goal was to defy manuscript conceptualization as a steady and solemn object of knowledge, an icon of the immutable past.

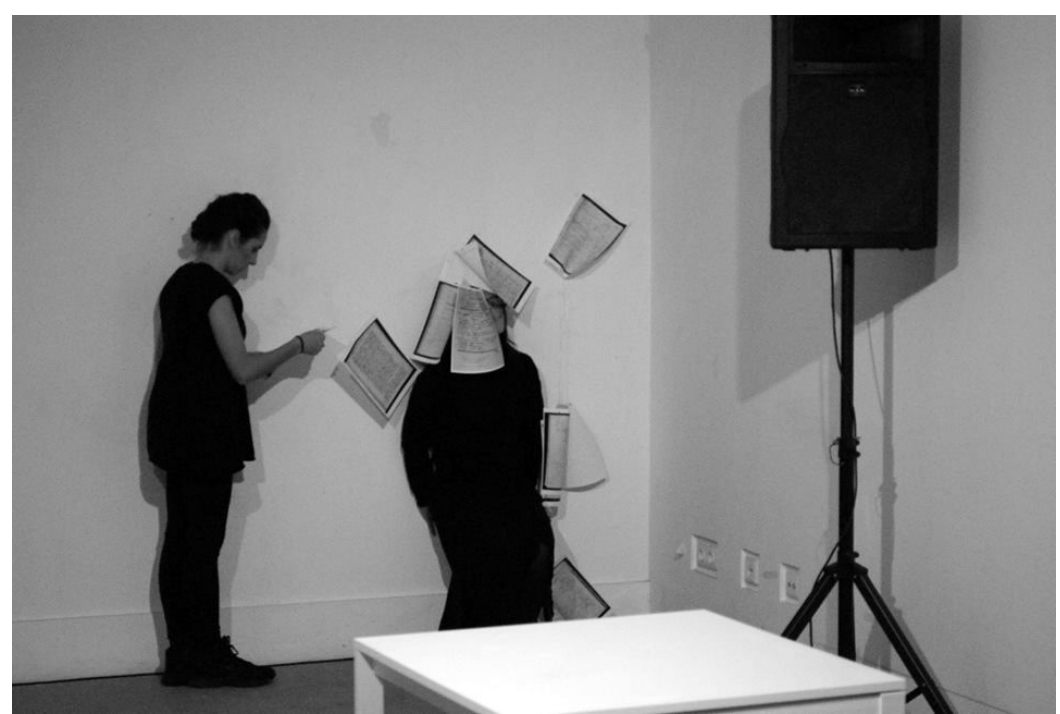

Figure 4. Author at Demimonde, Boavista Gallery, December 20, 2013. Photo: Freya group.

The manuscripts moved widely, as much as I could, so as to transform them into a symbol of mobility and rapid change. Nevertheless, they were always close to me as if complementing my body on the move. In this way, they no longer pertained to the silent, distant and ambiguous past, or either merely to my personal world, but were by then a part of the globalized world in which we all live. Inasmuch as this performance raises the question of distance and personal appropriation, it highlights the limits imposed upon the individual and self-expression by globalization: How difficult is it to express and communicate personal appropriation within a globalized world?

At this point, the boundaries between past, present, and future, and the borderline separating identities were flattened by means of both a redefinition of space and place, and a relocation of heritage. Framed by a subjective perspective, manuscripts were used to reach the Other, a complete stranger, with whom I shared a space for engagement and a place of encounter. Heritage was then the bound, the missing link.

It was important that someone noticed what I was doing, and furthermore how special and unique that could be. I succeeded insofar as the Other was trying to follow me, to get where I was heading, to give the right response to what I was demanding. At a certain point, we even engaged to- 
gether in a kind of sculpture using manuscripts and chairs, rediscovering uses and figures, in an attempt to challenge the audience's perception. However, as the performance goes on disclosing the centrality of manuscripts to interpersonal communication, the audience cannot avoid but noticing the hesitation and awkwardness on the part of the other performer, as if moving into a world where almost everything was out of place. At least, I was able to create a new landscape, full of physical engagement, and of attempts of encounter and communication, I would add, with something that has a long tradition of being steady, unshakable and immutable.

\subsubsection{What to Do When Everything Is Manuscript and Digital}

What about digital manuscripts? How does the body react to digital stimulation, specifically to eighteenth-century drama manuscripts, digitally manipulated, with varied forms and positions? The archive is thus technologically reconfigured, integrating the video of a performance, held at the studio of the National Foundation for Scientific Computation on 18 April 2014. Designed precisely for this context of media art, this video-performance endorses the creative exploration of the intersections of art, media and archive (Osthoff, 2009).

The intention behind this particular initiative was to question the premise that the complex universe of digital objects leads to generalized disembodiment. To achieve that, I looked for different responses in and through the body to extend, expand and transform the digital stimuli - in this case, the manuscripts. I sought to bring them to the surface of a new sensitivity, based on body movements that responded to each arrival of stimuli in a regular rhythm.

The sequence of digital manuscripts (Figure 5), with forms ranging from stellar to reversed, gave rise to a choreography in cadence, one under which the movement was processed in response to the arrival of a new digital stimuli, and thus originating brief moments of rupture in between stimuli. The movements aimed to highlight different situations, mediated by digital forms, within the difficulty of bodily interaction with the digital. This challenge calls for the acceptance of the protocols of a never-ceasing visual and iconographic world, which, in turn, urges for a fresh way of perceiving.

For this solo, I chose a full-length black dress, with disproportionately long red sleeves at the end. I wanted to resemble a black silhouette - although wearing the possibility of color against the gray landscape of digital manuscripts - in order to both highlight and emphasize the movement. My appearance predicted an undetermined origin between the world of video games, the circus art, and postmodern eccentricity. 


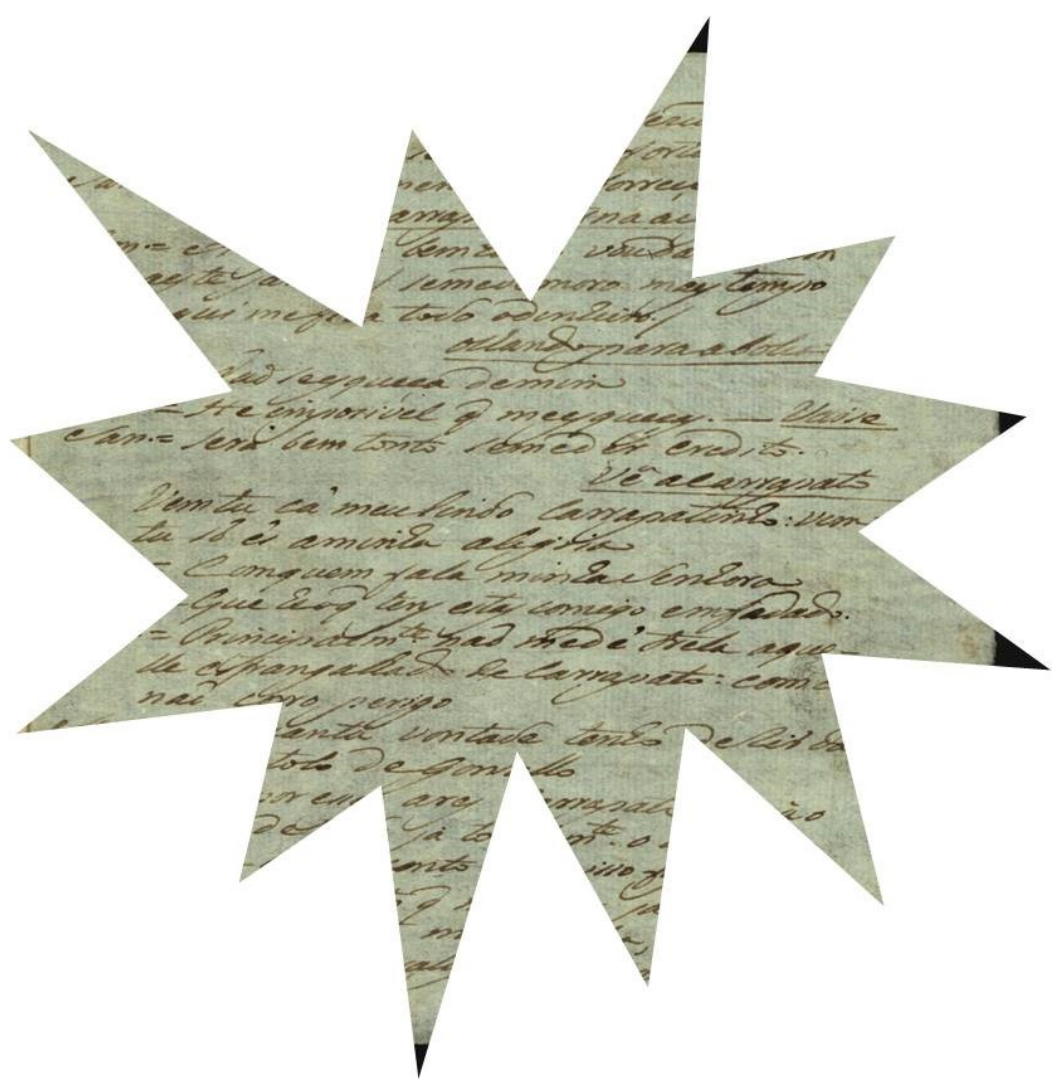

Figure 5. One of the manuscript forms of the video performance, recorded at the studio of the National Foundation for Scientific Computation, April 18, 2014. Photo: Author.

4.1.3 The Nymph Syrinx, or the Love Between Pan and Syrinx [A Ninfa Siringa ou Os Amores de Pan e Siringa] (1741)

The last performance took place on 8 October 2014, at the National Library of Portugal, as part of the exhibition From Manuscript to Performance: the collection of António José de Oliveira, on display from October 1 to December 31, 2014. I worked with Sérgio das Neves and Eunice da Silva, actors from the Freya group, to stage an excerpt of each act of the opera The Nymph Syrinx, or the Love Between Pan and Syrinx, by Alexandre António de Lima, first published in 1760, although premiered earlier, for the Carnival of 1741, at Bairro Alto Theatre.

An important and fundamental assumption was that the exhibition area should work and be articulated as setting, where all the subsequent action would unfold. The exhibition was composed of six display sets, with a selec- 
tion of drama manuscripts from the collection of António José de Oliveira, and an advertising poster.

The opera excerpts were chosen by me but were received with enthusiasm by the performers, who described them as comical and funny. The performance lasted about ten minutes, and it featured the main characters in the play of Alexandre António de Lima, namely Pan, Syrinx, Wafer and Gulosina. Sergio played the roles of Pan and Gulosina, and Eunice, Syrinx and Wafer. Syrinx and Pan are the masters, while Wafer and Gulosina are the servants who provide domestic service and any kind of assistance.

Mythology plays its role in the plot, since the episode of Pan and Syrinx comes from there: Pan is in love with Syrinx, who insists on despising him, not leaving him any other choice but to complain of his misfortune to Wafer, who, in turn, mocks Pan, assuming an unruly attitude toward the master. Gulosina, on the other hand, mirrors the attitude of her mistress, Syrinx, by also ignoring Wafer, who constantly proposes to her in the most lighthearted ways. The language of the play is full of ambiguities, resulting primarily from the performance of the servants, Wafer and Gulosina, as they question class division and introduce a sexual and erotic dimension into the discourse.

The performance turned out provocative and historical at the same time, because it appropriated ambiguity through a physical enactment that this opera lacked in its original version as shadow puppet theatre (Ameno, 1759). However, I believe that the same ambiguity could have been the object of an even more effective interpretation, and this can, in fact, be considered part of an ongoing work. The physical engagement of the performers established an interesting contrast with the confined space of the exhibition, with the display sets relatively close to each other. Accordingly, the space left in between could be explored as paths, for both the encounter and the mismatch of the characters (Figure 6): Pan sought Syrinx; Wafer found him, but then Wafer escaped; Syrinx was finally found, but then to prevent the match with Pan, she turned into reeds and was never to be seen again, only heard; but, after all, it was only Wafer hiding from Pan once more...

The artificiality of the comic opera of the first half of the eighteenth century determined the characterization of the performers whose exaggerated makeup made them resemble puppets, although not made of cork and moved by wire like the originals. Their black costumes were also an allusion to the shadow shows of Bairro Alto and Mouraria Theatres during the decades of 1730 and 1740. Additionally, singing moments underlined the formal specificities of the genre. 


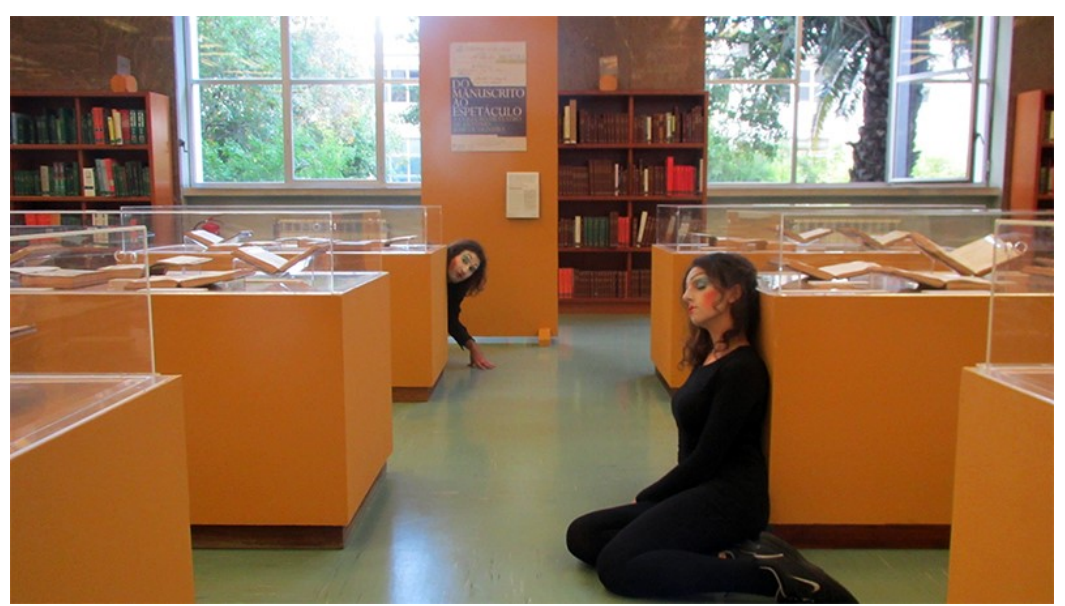

Figure 6. Sérgio das Neves and Eunice da Silva in The Nymph Syrinx, or The Love Between Pan and Syrinx, at the National Library of Portugal, on 8 October 2014. Photo: Author.

\subsection{Editing the "performance remains"}

On the whole, these three moments can be understood as an experimental way of rethinking the limits of the archive by engaging in the "take place" (Kobialka, 2002) contained in drama manuscripts. As posed by Clarke (2013), the scholar's interaction with art history can use performance art as a method, namely to develop a new insight into categories like document, text and edition. These three initiatives were experimental steps to prepare an improved reading edition of a selected set of unpublished eighteenth-century drama manuscripts.

Each of these performances contributed to an orienting principle of the electronic edition:

- "Manuscript play" related to the idea that the edited play must assume a double functionality: the transmission of heritage and subjective interaction;

- The video-performance underlined the performative nature of drama manuscripts, even if digital;

- The performance of The Nymph Syrinx or, the Love between Pan and Syrinx showed how the physical preponderance of the characters' interaction can redefine 21 st century communicative purposes.

These considerations, then, elicited three priorities within this editorial project:

- The design of the edition was from its beginning totally conceived in digital terms, including the cover of each of the texts. Each cover was imagined and selected taking in consideration the visual impact of the digital environment, and also as a visual strategy to distinguish 
between plays, in order to facilitate a subjective interaction with each (Figure 7).

- There is no attempt of visual / graphic unity within the edition, differently from what happens with a printed book or many of its electronic versions: first, there is an introductory text, with the link to the manuscript at the National Library of Portugal; then there is the transcription of the front page of the manuscript, and, finally, the play.

- There was a deliberate concern in stressing the role of the characters (the name of the characters appears consistently in bold and uppercase style throughout the plays), and in separating the dialogue from the stage directions (always centered and bold) that mainly entail bodily actions (Figure 8). Since my focus was on performance, both as methodology and outcome, I worked on the accuracy between information facilitating enactment and the electronic layout. In this way, the assessment of the characters and their bodily actions becomes immediate on the screen.

As CONSTRÂNTIAS DE BELISARIO NA SUA MAIOR DDEADENCIA

Jean-François Marmontel

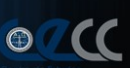

Figure 7. The cover of one of the edited plays (in collaboration with Gisela Canelhas): Bélisaire [As Constâncias de Belisário na sua Maior Decadência] (n.d.), by Jean-François Marmontel. 
TIBÉRIO: E ausentou-se sem me dizer quem fosse [7v] o herói que lamenta e seus motivos.

O que mais noto é ver o sentimento do singelo aldeão.

\section{Sai um CRIADO.}

CRIADO: Senhor Salácio, que a pouca distância te espera e a pé por não suportar o frio...

TIBÉRIO: Tão rigoroso o sinto eu juntamente e ao venal exercício não permite mais demoras; sim, vamos, nesse tronco o cavalo conduz, que a pé caminho.

CRIADO: Prontamente, senhor, vos obedeço. (Vai-se.)

\section{Sai SALÁCIO.}

SALÁCIO: Olá Tibério amigo, um pouco espera. TIBÉRIO: Mais avançado julguei que estarias.

Figure 8. An edited sample from Bélisaire [As Constâncias de Belisário na sua Maior Decadência] (n.d.), by Jean-François Marmontel.

Therefore, the visual clues of this edition are not attached to the book format or make explicit reference to it. Accordingly, the eight edited texts launched online on January 2015 should not be called volumes or even electronic books. They are plays that try to relate as much as possible to specific material forms, starting with the manuscript materiality itself which comprises, as aforementioned, the presence and distribution of a type of ink, the use of a certain quality of paper, the number of lines per page, the combination between speeches and stage directions, etc. Of course, to a certain extent the manuscript materiality itself connects to book layouts. That said, I can assert that the commitment of this editing project to the book format is limited to that circumstance. Hence, when preparing the electronic edition of the plays, book layouts were never considered as criteria for choosing between alternative displays. On the other hand, these plays were specifically edited in a manner that is thought to benefit their performative use and reuse. In other words, they are supposed to engender and participate in new performative practices that attest to the functionality of the repertoire and of "performance remains" as grounds for scholarly engagement in the rethinking of the concept, methods and modes of deliverance of edited material. Overall, the 
emphasis on the characters on scene and their bodily actions nurtures a more direct contact with the performative possibilities within each play.

\section{Conclusion}

When faced with the challenge of an electronic edition of eighteenth-century Portuguese drama manuscripts not yet published, I turned to performance art as an active methodology. Nevertheless, I was well aware of the richness of information of metadata options, and I knew that in that context the specificity of drama was already being considered. But I wanted to approach it in a new perspective, one that nourished the materiality of editing at first hand, mainly relying on the concept of "performative materiality" (Drucker, 2013) to justify the editor's response to multiple material layers. From there, I strove to relate electronic editing to the durability of performance beyond its moment of happening, allowing my allegedly ephemeral performance experience with the plays to shape their electronic display. Based on different performance initiatives, I have come to argue that the repertoire (Taylor, 2003) and "performance remains" (Schneider, 2001) can take action in the preparation of an electronic reading edition of the archive, laying bare the ongoing dynamics between scholarly research and performance art (Clarke, 2013). Even more conspicuously, my ongoing project of digital edition of eighteenth-century manuscript drama proposes a theoretical and methodological connection between the formal specificities of dramatic literature, its enactment and the visual features of the edited plays.

\section{References}

ANONYMOUS (1784). Comédia intitulada Não se Vence a Natureza. Cópia de António José de Oliveira [BNP, COD. 1383//5]. http://purl.pt/23968. - (1796). Comédia Nova Intitulada O Vassalo Mais Fiel no Cerco de Guimarães. Cópia de António José de Oliveira [BNP, COD. 1370//4]. http://purl.pt/15339.

AMENO, Francisco Luís, ed. (1759). Teatro Cómico Português on Colecção das Óperas Portuguesas I. Lisboa: Oficina Patriarcal de Francisco Luís Ameno.

BORGGREEN, Gunhild, Rune Gade (2013). "Introduction: The Archive in Performance Studies." Performing Archives/Archives of Performance. Eds. Gunhild Borggreen and Rune Gade. Copenhagen: Museum Tusculanum Press. 9-34.

CLARKE, Paul (2013). "Performing the Archive: The Future of the Past." Performing Archives/Archives of Performance. Ed. Gunhild Borggreen and Rune Gade. Copenhagen: Museum Tusculanum Press. 363-385. 
DAHLSTRÖM, Mats (2009). “The Compleat Edition.” Text Editing, Print and the Digital World. Eds. Marilyn Deegan and Kathryn Sutherland. Farnham: Ashgate. 27-44.

DEEGAN, Marilyn, Kathryn Sutherland, eds. (2009). Text Editing, Print and the Digital World. Farnham: Ashgate.

DRUCKER, Johanna (2009). SpecLab: Digital Aesthetics and Projects in Speculative Computing. Chicago: The University of Chicago Press.

(2013). "Performative Materiality and Theoretical Approaches to Interface.” Digital Humanities Quarterly 7.1. 22 Jun. 2016.

http://www.digitalhumanities.org/dhq/vol/7/1/000143/000143.html.

GANTS, David (2006). "Drama Case Study: The Cambridge Edition of the Works of Ben Jonson." Electronic Textual Editing. Eds. Lou Burnard, Katherine O'Keefe and John Unsworth. New York: Modern Language Association of America. 122-136.

GOLDONI, Carlo (1782). Comédia Nova Intitulada O Homem Vencedor. Cópia de António José de Oliveira [BNP, COD. 1372//4; F.R. 573]. http://purl.pt/15350.

(1782). Comédia Intitulada Molière ou Segunda Parte de Tartufo. Cópia de António José de Oliveira [BNP, COD. 1370//2; F.R. 14].

GORDON, Ann (2015). "Editing Death: An Element of Craft." Scholarly Editing 36. http://scholarlyediting.org/2015/essays/essay.gordon.html.

GROSS, Gerald, ed. (1993). Editors on Editing. 3rd ed. New York: Grove Press.

KIRSCHENBAUM, Matthew (2008). Mechanisms: New Media and the Forensic Imagination. Cambridge MA: MIT Press.

KOBIALKA, Michal (2002). "Historical Archives, Events and Facts: History Writing as Fragmentary Performance.” Performance Research 7.4: 3-11.

LIMA, Alexandre António de (1760). "A Ninfa Siringa ou Os Amores de Pan e Siringa." Teatro Cómico Português ou Colecção das Óperas Portuguesas III. Ed. Francisco Luís Ameno. Lisboa: Oficina Patriarcal de Francisco Luís Ameno. 86-187. http://purl.pt/16454.

LUSITANO, Cândido (pseud. de Francisco José Freire) (1782). Ópera intitulada Ulisses em Lisboa. Cópia de António José de Oliveira [BNP, COD. 1379//1]. http://purl.pt/16494.

MANOFF, Marlene (2006). "The Materiality of Digital Collections: Theoretical and Historical Perspectives." Libraries and the Academy 6.3: 311-325. 20 Jun. 2016. http://hdl.handle.net/1721.1/35689.

MARMONTEL, Jean-François (n.d.). Segunda parte das últimas aç̧ões do valeroso capitão ou Tragédia intitulada As constâncias de Belisário na sua maior decadência. Cópia de António José de Oliveira [BNP, COD. 1383//6]. http://purl.pt/23969.

MCGANN, Jerome (1997). “The Rationale of Hypertext." Electronic Text: Investigations in Method and Theory. Ed. K. Sutherland. Oxford: Clarendon Press. 19-46. 
MUELLER, Martin (2014). "Shakespeare His Contemporaries: collaborative curation and exploration of Early Modern drama in a digital environment." Digital Humanities Quarterly 8.3. 20 Jun. 2016.

http://www.digitalhumanities.org/dhq/vol/8/3/000183/000183.html.

PORTELA, Manuel (2014). "Multimodal Editing and Archival Performance:

A Diagrammatic Essay on Transcoding Experimental Literature.” Digital Humanities Quarterly 8.1. 20 Jun. 2016.

http://www.digitalhumanities.org/dhq/vol/8/1/000175/000175.html.

SCHNEIDER, Rebecca (2001). "Performance Remains." Performance Research 6.2: 100-108.

SILVEIRA, Jerónima Luísa da (1783). Nova e Verdadeira História do Triunfo da Rainha de Volsco. Cópia de António José de Oliveira [BNP, COD. 1366//3]. http://purl.pt/24577.

TAYLOR, Diana (2003). The Archive and the Repertoire: Performing Cultural Memory in the Americas. Durham, NC: Duke University Press.

VANHOUTTE, Edward (2009). "Every Reader his own Bibliographer - An Absurdity?" Text Editing, Print and the Digital World. Eds. Marilyn Deegan and Kathryn Sutherland. Farnham: Ashgate. 99-112.

VOLTAIRE (pseud. François Marie Arouet) (1795). Nova Tragédia intitulada Mafoma ou Fanatismo. Cópia de António José de Oliveira [BNP, COD. 1388//2]. http://purl.pt/16461.

(C) 2016 Isabel Pinto.

Licensed under the Creative Commons Attribution-NoncommercialNo Derivative Works 4.0 International (CC BY-NC-ND 4.0). 